\title{
СУЧАСНІ МОЖЛИВОСТІ ЗАСТОСУВАННЯ ДЕТОКСИКАЦИЙНИХ ЛАЗЕРНИХ ПРОГРАМ ПРИ КУПІРУВАННІ ЗАПІЙНИХ ФОРМ АЛКОГОЛІЗАЦІї
}

\section{MODERN POSSIBILITIES OF APPLICATION OF DETOXIFICATION LASER PROGRAMS WHEN MITIGATING DRINKING FORMS OF ALCOHOLIZATION}

\section{Юрій Чуєв (Yurii Chuiev) ${ }^{1}$ \\ 1 Медичний Центр «Авіценна», Харків, Україна (Medical Center "Avicenna", Kharkiv, Ukraine) \\ "Corresponding author: Yurii Chuiev, affiliated to Medical Center "Avicenna", Kharkiv, Ukraine}

Abstract. In recent years, there has been a significant complication of the clinical picture of somatoneurological and mental status of patients with intoxicated forms of alcohol dependence. The aim of the study was to clinically evaluate the effectiveness of the innovative complex in the complex and the development of a therapeutic algorithm for its use in drug practice. The object of our scientific and practical interests in recent years has been modeling, testing and implementation of a new generation of non-drug and pharmacological methods of treatment of acute and urgent drug pathology, and its consequences, creating a set of innovative laser treatment and rehabilitation programs. The therapeutic efficacy of the laser infusion therapeutic complex was evaluated using pretreatment rating scales, first, third and fifth days of treatment. In the course of therapy a clinical and laboratory study, general blood and urine tests, biochemical blood test were performed. Based on the data, we can conclude about the high efficiency of laser infusion detoxification as a means of alleviating the drunken form of alcohol dependence. The rate of reduction of somatoneurological and
Received: August 10, 2021

Published: August 23, 2021 psychopathological disorders was significantly higher in the case of using an innovative treatment module based on laser technology than in the process of therapy with traditional drugs. Clinical interpretation of the obtained results in the main group allowed recording the tendency to a more pronounced positive dynamics, which manifested in a smoother disappearance of post-intoxication symptoms. In our opinion, the main clinical feature of the laser complex is the differences in the intensity of the positive therapeutic effect, indicating the presence of pronounced detoxifying properties. Thus, the therapeutic effects of the proposed laser detoxification program are extremely necessary to alleviate the drunken form of alcohol dependence in drug practice. The obtained results expand the current possibilities of etiopathogenetic therapy and allow recommending the inclusion of the developed method in complex therapeutic and rehabilitation programs for the treatment of drug addicts.

Keywords: alcohol dependence, detoxification laser programs, etiopathogenetic therapy.

Вступ. Останніми роками спостерігається значне ускладнення клінічної картини соматоневрологічного i психічного статусу хворих із запійними формами алкогольної залежності (АЗ). Накопичується все більше даних про роль запійних станів у генезі гострих алкогольних психозів, судомних нападів, алкогольної поліневропатії, синдрому раптової смерті, постінтоксикаційних 
соматоневрологічних розладів, інтелектуально-мнестичних порушень, органічних уражень центральної нервової системи з явищами деменції. У такому стані хворі вимагають невідкладної медичної допомоги за життєвими показаннями в умовах спеціалізованого відділення. Подальше вживання алкоголю стає небезпечним для їх життя, загрожує розвитком тяжкої алкогольної інтоксикації з фатальними наслідками. Купірування запоїв вимагає реалізації індивідуалізованих і суворо диференційованих лікувально-реабілітаційних програм, а розробка інноваційних підходів до купірування станів запою є однією 3 найактуальніших проблем сучасної наркології $[1,2,3]$.

Об'єктом наших науково-практичних інтересів останніх років стало моделювання, апробація і впровадження нового покоління немедикаментозних і фармакологічних методів лікування гострої і невідкладної наркопатологіi, та іiі наслідків, створення комплексу інноваційних лазерних лікувальновідновлювальних програм. Накопичений досвід показав, що даний напрямок $\epsilon$ стратегічно виправданим і патогенетично обгрунтованим $[4,5,6]$.

Метою даного дослідження було клінічне оцінювання ефективності використання інноваційного комплексу (внутрішньосудинна лазерна гемотерапія + інфузійна терапія, яка передбачала поетапне введення на протязі доби розчину Реосорбілакту та 5\%-го розчину глюкози + карбамазепін + гепатопротектори Л'есфаль і Антраль) у комплексній терапії запійної форми алкогольної залежності і розробка терапевтичного алгоритму його застосування в наркологічній практиці. У клінічній наркології одним 3 основних лазерних методів детоксикації при терапії невідкладних станів (гостра інтоксикація алкоголем, синдром відміни алкоголю, запійні форми алкогольної залежності) $\mathrm{e}$ метод внутрішньосудинної лазерної гемотерапіі (ВЛГ). Досвід показує, що даний метод доцільно застосовувати в комбінації 3 інфузійними i екстракорпоральними методами терапії, які потенціюють лікувальні ефекти один одного. Регістр саногенетичних і патогенетичних ефектів лазерної медицини при купіруванні невідкладної наркопатологіi пояснюється детоксикаційними, биостимулирующими, иммунокоригуючими, мікроциркуляторними, антиоксидантними, і метаболічнними ефектами. Нами встановлений також спектр психотропної активності лазерної терапії: виражені тімолептичні (зокрема, антидепресивні) ефекти, анксіолітична (антітревожна) дія, стимулююча дія (редукція апатії, байдужості), які є важливими при купіруванні запійних станів.

Реосорбілакт має реологічну, протишокову, дезінтоксикаційну, регідратуючу дію, запобігає розвитку запальних реакцій, поліпшує мікроциркуляцію i перфузію тканин, артеріальний i венозний кровообіг, відновлює водно-електролітний баланс. Поповнює дефіцит іонів натрію і хлору при різних патологічних станах, що супроводжуються масивною інтоксикацією. Основними фармакологічно активними речовинами препарату $\epsilon$ сорбітол i натрію лактат. Реосорбілакт застосовують в клінічній наркології при невідкладних станах алкогольного генезу, коморбідних з хронічним гепатитом 
та панкреатитом у стадії загострення. Реосорбілакт вводили внутрішньовенно, краплинно, по 200-400 мл 2 рази на добу, до 4-6 інфузій на курс лікування.

Відомо, що 5\%-й розчин глюкози для інфузій підсилює окисно-відновні процеси в організмі, поліпшує антитоксичну функцію печінки. Вливання розчинів глюкози частково заповнює водний дефіцит. Розчин, потрапляючи до тканин, фосфорилюється, перетворюючись на глюкозо-6-фосфат, який активно залучається до численних ланок обміну речовин організму. 5\%-й розчин глюкози має значний детоксикаційний ефект, унаслідок метаболізму інфузійного препарату в тканинах виділяється значна кількість енергї, необхідної для життєдіяльності організму. Призначається 5\% розчин глюкози пацієнтам 3 запійними формами алкоголізації з тяжкими інтоксикаційними анорексіями, після клінічного обстеження та під контролем їі змісту в крові і сечі.

За даними літератури (І.К. Сосін, І.В. Купрієнко, 1995), нападоподібноциклічний характер запійних форм алкоголізації і властивий їм епілептиформний синдром, часті дисфоричні стани, наявність спільних 3 епілепсією патогенетичних ланок, зокрема, наявність пароксизмальності в біоелектричній активності головного мозку $\epsilon$ передумовою включення до програми інтенсивної терапії 3 метою купірування запійного нападу антиконвульсанта-тимолептика карбамазепіну, який має мінімальну кількість побічних ефектів, незначну міорелаксуючу дію, не спричиняє звикання. Застосування антиконвульсанта карбамазепіну як монотерапії у випадках алкогольної залежності впливало позитивно на симптоми тривожності й депресії, а також знижувало дратівливість та агресивність хворих. Застосований у разі запійного стану, карбамазепін підвищує поріг судомної готовності i зменшує вираженість клінічних проявів синдрому відміни, зокрема, безсоння, тривога, страх, збудливість, тремор, порушення ходи. Підтверджено ефективність карбамазепіну як психотропного засобу у випадках афективних порушень, у комбінації з нейролептиками, антидепресантами або препаратами літію. Дані наведених вище досліджень стали передумовою для включення карбамазепіну до комплексної терапії запійних форм алкоголізації на основі лазерних інновацій.

Одним 3 основних завдань купірування запійного статусу стало коригування токсичної гіперферментемії, яка, на нашу думку, зумовлює тяжкий перебіг алкогольної залежності та асоційованих соматоневрологічних розладів. Відомо, що основною мішенню інтоксикаційної дії етанолу для запійних станів $\epsilon$ печінка, що стає причиною іiі дисфункції (алкогольна гепатомегалія, стеатоз, алкогольний фіброз, гострий і хронічний алкогольний гепатит, цироз). У хворих iз запійними формами перебігу алкогольної залежності підвищується активність ферментів печінки - аспартатамінотрансферази (АсАТ), аланінамінотрансферази (АлАТ), гамма-глутамілтрансферази (ГГТ), а також рівні деяких інших біохімічних показників (лужної фосфатази, холестерину, загального білірубіну), з'являються електролітні порушення (гіпонатремія, гіпокаліємія, гіпомагніємія, гіпофосфатемія), дихальний алкалоз. 
У зв'язку з цим застосування нових препаратів гепатопротекторної дії, здатних активувати ферменти, що метаболізують етанол, прискорювати процеси окиснення та елімінації етанолу й ацетальдегіду, перешкоджати виникненню первинної структурної дегенерації гепатоцитів, знижувати імовірність розвитку фіброзу та цирозу печінки, виявляти ад'ювантні детоксикаційні властивості, $\epsilon$ актуальним завданням наукової наркології. Одними з таких гепатопротекторів нового покоління, які привернули нашу увагу, $\epsilon$ препарати Л'есфаль і Антраль.

Відомо (І.К. Сосін, 2015), що синхронне застосування внутрішньовенної та пероральної лікарських форм гепатопротекторів нового покоління ад'ювантно впливає на різні патогенетичні механізми алкогольного ураження функцій печінки. Розроблено алгоритм застосування інноваційної гепатопротекторної комбінації, який включає застосування препарату Л'есфаль і препарату Антраль.

Препарат Л'есфаль містить фосфоліпіди, які прискорюють регенерацію пошкоджених тканин печінки і позитивно впливають на обмін жирів за допомогою регуляції метаболізму ліпопротеїнів, сприяють приєднанню холестерину до ліпопротеїдів високої щільності, нормалізують склад жовчі. Л'есфаль застосовують в комплексній терапії жирової дистрофії печінки, гепатиту, токсичного ураження печінки (наркотичного, алкогольного, лікарського), цирозу печінки, порушень функції печінки. Л'есфаль призначають по 5,0 мл внутрішньовенно на автокрові, щодня один раз на добу, курсом 5-10 ін'єкцій.

Препарат Антраль належить до групи гепатопротекторних препаратів останнього покоління. Він $є$ ефективним у лікуванні гострих і хронічних гепатитів різного генезу, гепатозів, цирозів печінки, сприяє зменшенню астеновегетативних порушень, покращує апетит, сон, зменшує диспептичні явища. Курсове застосування препарату нормалізує вміст білірубіну, $\gamma$ глобулінів, холестерину в крові, протромбіновий індекс, активність трансаміназ (АлАТ і АсАТ) і лужної фосфатази. Антралю притаманні пролонговані протизапальна та знеболювальна дія. За результатами доклінічних досліджень встановлено, що Антраль в умовах гострого, підгострого i хронічного ушкодження печінки різними ксенобіотиками та їх комбінаціями сприяє послабленню наслідків дії гепатотоксинів, активізації репаративних процесів у гепатоцитах i практичній нормалізації рівнів показників структурнофункціонального стану печінки. Антраль сумісний із детоксикуючими, жовчогінними, вітамінними препаратами, що дозволяє включити його в комплекси лікування алкогольної залежності. Антраль призначають внутрішньо після їжі 3 рази на добу: по 200 мг на прийом, середній курс лікування становить 2-3 тижні.

Матеріали та методи. Під нашим спостереженням перебувало 75 хворих (всі чоловіки віком від 31 до 52 років), яких госпіталізували за невідкладними показаннями для лікування, із запійними формами алкогольної залежності. Клінічно стан хворих рубрифікований у 51 спостереженні як компульсивна фаза запійного стану, і в 24 - як постзапійний синдром. У всіх спостереженнях, внаслідок пролонгованої і масивної інтоксикації, на фінальних стадіях запою 
розвивався тяжкий синдром відміни із загальним психофізичним виснаженням, вираженими вегетативними $\mathrm{i}$ неврологічними розладами, численними психопатологічними елементами, стійкою анорексією з нудотою і блюванням. Хворі були тривожними, метушливими, відчували безпредметний страх. Спроби полегшити свій стан прийомом чергової дози спиртного, як правило, не приводили да бажаного ефекту. У деяких випадках пацієнти відчували уривчасті зорові і слухові галюцинації, які спонтанно з'являлися і зникали. Порушення сну, як правило, досягали ступеня повної агрипнії навіть за триваючої алкоголізації. Нічні пробудження супроводжувалися страхом смерті, тривогою, «вольєрним» ходінням по квартирі, болісною депресією, ідеями самознищення. У 4 випадках запійний період характеризувався появою розгорнутих судомних нападів. Напередодні госпіталізації у більшості хворих знижувалася настирливість й активність у пошуках спиртного, разова толерантність знижувалася до 50-70 мл горілки і менше, поступово доходячи до повної інтолерантності. Подальше вживання алкоголю ставало небезпечним для життя, загрожувало розвитком тяжкого алкогольного отруєння з фатальними наслідками, що призводило до неминучого ушпиталення.

Для реалізації мети дослідження хворим основної групи (55 хворих) була призначена комплексна терапія, що включає курс ВЛГ на тлі інфузії розчину Реосорбілакту по 200 мл (ранок, обід), та ввечері 5\%-го розчину глюкози 200 мл, i стандартної медикаментозної терапії із застосуванням антиконвульсанта карбамазепіну по 100-200 мг 3 рази на день (курс 6-8 днів) і комбінації гепатопротекторів: препарат Л'есфаль 5,0 мл внутрішньовенно 1 раз на день на автокрові (№ 7-10 на курс) і препарат Антраль по 0,2 г 3 рази на день (14-21 день на курс).

Хворі контрольної групи (20 пацієнтів) отримували тільки традиційну медикаментозну терапію. Основну і контрольну групи хворих добирали 3 аналогічними віковими характеристиками та анамнестичними даними, давністю захворювання на алкогольну залежність, тривалістю масивної алкоголізації напередодні госпіталізації до наркологічного стаціонару. В основній групі величина вікового показника становила $49,22 \pm 4,57$ року, в групі контролю 51,12 $\pm 3,97$ року, давність запійної форми алкоголізації в основній групі дорівнювала $16,57 \pm 2,14$ року, в контрольній $15,87 \pm 3,64$ року.

Терапевтичну ефективність лазерного інфузійного терапевтичного комплексу оцінювали за допомогою шкал оцінок до лікування, 1-й, 3-й і 5-й день перебування на лікуванні. Застосовували шкали психопатологічних проявів; соматоневрологічних проявів; клінічного враження.

У процесі терапії проводили клініко-лабораторне дослідження, загальні аналізи крові та сечі, біохімічний аналіз крові (АсАТ, АлАТ, ГГТ, холестерин, лужна фосфатаза, білірубін). Вимірювали величини гемодинамічних показників, частоту дихальних рухів, проводили електрофізіологічні дослідження: реоенцефалографію (РЕГ), електроенцефалографію (ЕЕГ), електрокардіографію (ЕКГ). Упродовж дослідження розраховували коефіцієнт де Рітіса (співвідношення активності сироваткових АсАТ та АлАТ. 
Результати та обговорення. Огляд, проведений у перші години в лікарні у хворих основної та контрольної груп (Табл. 1,2$)$ виявляв чіткий гіпертензійний синдром з регістрами артеріального тиску від 160/100 до 200/100 мм рт. ст. і вище, частота серцевих скорочень (ЧСС) досягала 110-120 ударів за хвилину. Все це супроводжувалося задишкою (в середньому понад 22-24 дихальних рухів за хвилину), загальним тремором, порушенням статики і координації, навіть до адинамії хворого. Електрокардіографічні дослідження виявляли різні постінтоксикаційні ураження серця: синдром порушення реполяризації шлуночків, порушення провідності, порушення збудливості у вигляді екстрасистолій і тахікардії. ЕЕГ-дослідження реєструвало помірні і виражені порушення гемоліквородинаміки 3 ЕЕГ-ознаками дисфункції стовбура i готовності до пароксизмів. Реоенцефалографічне дослідження практично у всіх хворих виявляло патологічні зміни у вигляді вираженого спазму судин зі зниженням їх кровонаповнення, реєструвалося значне уповільнення припливу крові через ригідність і порушення тонічного стану судинної стінки, спостерігався поліморфізм РЕГ-кривих.

Таблиця 1. Схема базової терапії запійної форми АЗ в основній групі.

\begin{tabular}{|c|l|l|}
\hline \multicolumn{2}{|c|}{ Найменування препарату } & Середня добова доза \\
\hline 1 & ВЛГ & $2-3$ сеанси \\
\hline 2 & Реосорбілакт & до 400 мл 2 рази \\
\hline 3 & Розчин глюкози 5\%-й & до 200 мл \\
\hline 4 & Гідазепам & 20 мг 3 рази \\
\hline 5 & Вітамін $\mathrm{B}_{1}$ & 2 мл 2-3 рази \\
\hline 6 & Вітамін $\mathrm{B}_{6}$ & $2-4$ мл 2 рази \\
\hline 7 & Вітамін $\mathrm{B}_{12}$ & $1-2$ мл 1 раз \\
\hline 8 & Вітамін С 5\%-й & 4 мл 2 рази \\
\hline 9 & Рибоксин 2\%-й & 10 мл 2 рази \\
\hline 10 & МgSО 4 25\%-й & $5-10$ мл 2 рази \\
\hline 11 & Лазикс & $20-40$ мг в/в \\
\hline 12 & Карбамазепін & $100-200$ мг 3 рази \\
\hline 13 & Л'есфаль & 5,0 мл в/в \\
\hline 14 & Антраль & 200 мг 3 рази \\
\hline
\end{tabular}

Таблиця 2. Схема базової терапії запійної форми АЗ в контрольній групі.

\begin{tabular}{|l|l|l|}
\hline \multicolumn{2}{|l|}{ Найменування препарату } & Середня добова доза \\
\hline 1 & Реосорбілакт & до 400 мл 2 рази \\
\hline 2 & Розчин глюкози 5\%-й & до 200 мЛ \\
\hline 3 & Вітамін $\mathrm{B}_{1}$ & 2 мл 2-3 рази \\
\hline 4 & Вітамін $\mathrm{B}_{6}$ & $2-4$ мл 2 рази \\
\hline 5 & Вітамін $\mathrm{B}_{12}$ & $1-2$ мл 1 раз \\
\hline 6 & Вітамін С $5 \%$-й & 4 мл 2 рази \\
\hline
\end{tabular}


SSP Modern Pharmacy and Medicine (ISSN 2733-368X), Volume 1 Issue 1 August 2021

\begin{tabular}{|c|c|c|}
\hline 7 & Рибоксин 2\%-й & 10 мл 2 рази \\
\hline 8 & $\mathrm{MgSO}_{4} 25 \%$-й & $5-10$ мл 2 рази \\
\hline 9 & Лазикс & 20-40 мГ в/в \\
\hline 10 & Гідазепам & 20 мг 3 рази \\
\hline 11 & Глутаргін & 750 мг на добу \\
\hline
\end{tabular}

У першу добу перебування хворого на лікуванні інфузію розчину Реасорбілакту проводили 2 рази на добу (ранок, обід) в периферичні вени одноразово в кількості 200 мл, швидкість вливання становила до 40-60 крапель за хвилину. Процедуру проводили на тлі внутрішньосудинної лазерної гемотерапії. Проведення комбінованої детоксикації приводило до стабілізації і поліпшення загального стану хворого. Клінічно це проявлялося 3-4 години поспіль у вигляді часткової редукції гастритичних розладів і гепатоалгії, зникнення нудотно-блювального стану, відносної нормалізації рівнів гемодинамічних показників, поліпшення якості координаційних проб. Ввечері додатково вводили 200 мл 5\%-го розчину глюкози з комплексом вітамінів (3-5 мл 6\%-го розчину вітаміну В1, 3-5 мл 5\%-го розчину вітаміну В6, 5-10 мл 5\%-го розчину аскорбінової кислоти), розчин магнію сульфату 5-10 мл в/м. Наше дослідження показало, що внутрішньовенні вливання 5\%-го розчину глюкози на тлі ВЛГ при тяжких, тривалих і масивних запоях здатні на початкових етапах терапії істотно стимулювати природні механізми детоксикації, забезпечити розвиток метаболічних процесів убік їх посилення, усунути явища інтоксикаційної анорексії. Дане положення вимагає подальшого поглибленого теоретичного обгрунтування та вивчення.

3 метою купірування компульсивного потягу до вживання алкоголю призначали карбамазепін у дозуваннях до 600 мг на добу. У комплексі засобів і методів обривання запійного статусу широко використовували гідазепам по 2040 мг 3 рази на добу. Проведення цих лікувальних заходів поліпшувало психічний і соматоневрологічний стан до кінця першої доби, запобігаючи розвитку тяжких абстинентів розладів. На другу та третю добу добові дози розчину Реосорбілакту та 5\%-ї глюкози залишались незмінними, або по індивідуальним показанням могли знижуваться на 100-200 мл, та вводилися 2 рази на добу, вранці та ввечері. Курсове лікування тривало 3-4 дні, до значного відновлення психічних, неврологічних i соматичних функцій. Досвід купірування запійних станів показав, що застосування інтенсивних засобів детоксикації з використанням інфузійної комбінації реосорбілакту та 5\%-ї глюкози, карбамазепіну, Антраль, Л'есфаль на тлі ВЛГ уможливлює ефективне лікування запійного стану, дозволяє пом'якшити явища алкогольної абстиненції, яка настає згодом.

Упродовж наступних 2-3 днів комплексної терапії в обох групах хворих із запійними формами алкогольної залежності тривали розлади депресивного спектра; тривога, знижений фон настрою, дратівливість 3 чітко окресленими клінічними варіантами дисфорії, внутрішня напруженість, порушення формули сну. За даними анамнезу, зі слів хворих, вихід із запою у них завжди 
супроводжувався астенічними проявами, дратівливістю, слабкістю, млявістю, швидкою стомлюваністю, нестійкістю уваги. Особливістю клінічної картини запою в обох групах був астенічний симптомокомплекс.

Протягом проведення активної терапії стан хворих поліпшувався в обох групах $з$ акцентом на деякі клінічні відмінності. Вплив на потяг до алкоголю, погіршення настрою, рухове збудження і субпсихотичні розлади можна було визначити як виражений або схожий.

Отримані в процесі терапії дані відображені в сумарних шкалах динаміки психопатологічних і соматоневрологічних проявів у структурі постзапійного статусу (Табл. 3). Стан хворих оцінювали під час прийому на лікування і потім щодня вранці до проведення терапевтичних заходів, протягом 1-го, 3-го та 5-го днів (Табл. 4). Ступінь вираження кожного симптому визначали в балах від 0 до 3 (0 - симптом відсутній, 1 - слабко виражений, 2 - виражений, 3 - сильно виражений).

Таблиця 3. Динаміка психопатологічних проявів у процесі лазерної детоксикації запійних форм алкогольної залежності.

\begin{tabular}{|c|c|c|c|c|}
\hline Симптом & $\underset{\text { Дікування }}{\text { День }}$ & $\begin{array}{c}\text { Основна } \\
\text { група }\end{array}$ & $\begin{array}{c}\text { Контрольна } \\
\text { група }\end{array}$ & $\mathbf{p}$ \\
\hline \multirow{4}{*}{ Потяг до алкоголю } & 0 & $2,66 \pm 0,11$ & $2,69 \pm 0,12$ & $>0,05$ \\
\hline & 1 & $2,20 \pm 0,10$ & $2,49 \pm 0,13$ & $>0,05$ \\
\hline & 3 & $1,75 \pm 0,22$ & $1,91 \pm 0,21$ & $>0,05$ \\
\hline & 5 & $1,05 \pm 0,10$ & $1,45+0,33$ & $>0,05$ \\
\hline \multirow{4}{*}{ Інсомнічні розлади } & 0 & $2,45 \pm 0,12$ & $2,39 \pm 0,17$ & $>0,05$ \\
\hline & 1 & $1,27 \pm 0,11$ & $1,91 \pm 0,17$ & $>0,05$ \\
\hline & $3 *$ & $0,84 \pm 0,22$ & $1,90 \pm 0,27$ & $<0,05$ \\
\hline & $5 *$ & $0,67 \pm 0,14$ & $1,35 \pm 0,16$ & $<0,05$ \\
\hline \multirow[t]{4}{*}{ Зниження настрою } & 0 & $2,68 \pm 0,16$ & $2,69 \pm 0,20$ & $>0,05$ \\
\hline & 1 & $1,33 \pm 0,17$ & $1,88 \pm 0,15$ & $>0,05$ \\
\hline & 3 & $1,12 \pm 0,13$ & $1,51 \pm 0,16$ & $>0,05$ \\
\hline & 5 & $0,92 \pm 0,12$ & $1,37+0,15$ & $>0,05$ \\
\hline \multirow[t]{4}{*}{ Тривога } & 0 & $2,52 \pm 0,11$ & $2,49 \pm 0,22$ & $>0,05$ \\
\hline & 1 & $1,91 \pm 0,18$ & $2,23 \pm 0,22$ & $>0,05$ \\
\hline & $3 *$ & $1,21 \pm 0,13$ & $1,76 \pm 0,20$ & $<0,05$ \\
\hline & $5^{*}$ & $0,71 \pm 0,15$ & $1,44 \pm 0,23$ & $<0,05$ \\
\hline \multirow[t]{4}{*}{ Страх } & 0 & $0,73 \pm 0,13$ & $0,69 \pm 0,16$ & $>0,05$ \\
\hline & 1 & $0,41 \pm 0,10$ & $0,53 \pm 0,15$ & $>0,05$ \\
\hline & 3 & $0,24 \pm 0,08$ & $0,39 \pm 0,14$ & $>0,05$ \\
\hline & $5 *$ & $0,06 \pm 0,05$ & $0,27 \pm 0,11$ & $<0,05$ \\
\hline \multirow[t]{4}{*}{ Дисфорія } & 0 & $1,70 \pm 0,11$ & $1,76 \pm 0,12$ & $>0,05$ \\
\hline & 1 & $1,49 \pm 0,12$ & $1,65 \pm 0,13$ & $>0,05$ \\
\hline & 3 & $1,29 \pm 0,12$ & $1,22 \pm 0,16$ & $>0,05$ \\
\hline & $5 *$ & $0,49 \pm 0,12$ & $0,83 \pm 0,12$ & $<0,05$ \\
\hline
\end{tabular}


SSP Modern Pharmacy and Medicine (ISSN 2733-368X), Volume 1 Issue 1 August 2021

\begin{tabular}{|l|c|c|c|c|}
\hline Рухове збудження & 0 & $0,36 \pm 0,13$ & $0,31 \pm 0,11$ & $>0,05$ \\
\cline { 2 - 5 } & 1 & $0,18 \pm 0,06$ & $0,22 \pm 0,09$ & $>0,05$ \\
\cline { 2 - 5 } & 3 & $0,00 \pm 0,00$ & $0,06 \pm 0,05$ & $>0,05$ \\
\hline \multirow{4}{*}{ Субпсихотичні розлади } & 5 & $0,00 \pm 0,00$ & $0,06 \pm 0,05$ & $>0,05$ \\
\cline { 2 - 5 } & 0 & $0,20 \pm 0,08$ & $0,24 \pm 0,10$ & $>0,05$ \\
\hline & 1 & $0,11 \pm 0,07$ & $0,20 \pm 0,09$ & $>0,05$ \\
\cline { 2 - 5 } & 3 & $0,08 \pm 0,04$ & $0,11 \pm 0,07$ & $>0,05$ \\
\hline & 5 & $0,00 \pm 0,00$ & $0,05 \pm 0,05$ & $>0,05$ \\
\hline
\end{tabular}

* Примітка. Результати представлені за схемою: середнє значення \pm довірчий інтервал для

$\mathrm{p}<0,05$.

Таблиця 4. Динаміка соматовегетативних проявів у процесі комплексної терапії запійних форм алкогольної залежності.

\begin{tabular}{|c|c|c|c|c|}
\hline Симптом & $\begin{array}{c}\text { День } \\
\text { лікування }\end{array}$ & $\begin{array}{c}\text { Основна } \\
\text { група }\end{array}$ & $\begin{array}{c}\text { Контрольна } \\
\text { група }\end{array}$ & $\mathbf{p}$ \\
\hline \multirow{4}{*}{ Гіпергідроз } & 0 & $2,37 \pm 0,14$ & $2,14 \pm 0,21$ & $>0,05$ \\
\hline & 1 & $1,54 \pm 0,19$ & $1,32 \pm 0,22$ & $>0,05$ \\
\hline & 3 & $1,20 \pm 0,14$ & $1,24 \pm 0,21$ & $>0,05$ \\
\hline & 5 & $0,91 \pm 0,14$ & $1,06+0,16$ & $>0,05$ \\
\hline \multirow[t]{4}{*}{ Тремор } & 0 & $2,31 \pm 0,12$ & $2,29 \pm 0,17$ & $>0,05$ \\
\hline & 1 & $1,81 \pm 0,10$ & $1,94 \pm 0,18$ & $>0,05$ \\
\hline & 3 & $1,23 \pm 0,16$ & $1,20 \pm 0,14$ & $>0,05$ \\
\hline & 5 & $1,09 \pm 0,16$ & $1,15 \pm 0,16$ & $>0,05$ \\
\hline \multirow[t]{4}{*}{ Озноб } & 0 & $0,71 \pm 0,08$ & $0,79 \pm 0,13$ & $>0,05$ \\
\hline & 1 & $0,51 \pm 0,11$ & $0,55 \pm 0,13$ & $>0,05$ \\
\hline & 3 & $0,35 \pm 0,11$ & $0,41 \pm 0,11$ & $>0,05$ \\
\hline & 5 & $0,27 \pm 0,08$ & $0,21+0,09$ & $>0,05$ \\
\hline \multirow[t]{4}{*}{ Тахікардія } & 0 & $2,12 \pm 0,14$ & $1,89 \pm 0,20$ & $>0,05$ \\
\hline & 1 & $1,41 \pm 0,11$ & $1,83 \pm 0,12$ & $>0,05$ \\
\hline & $3 *$ & $1,01 \pm 0,07$ & $1,54 \pm 0,13$ & $<0,05$ \\
\hline & $5^{*}$ & $0,87 \pm 0,12$ & $1,41 \pm 0,13$ & $<0,05$ \\
\hline \multirow[t]{4}{*}{ Відсутність апетиту } & 0 & $2,33 \pm 0,13$ & $2,16 \pm 0,16$ & $>0,05$ \\
\hline & 1 & $2,11 \pm 0,15$ & $2,13 \pm 0,18$ & $>0,05$ \\
\hline & $3 *$ & $1,18 \pm 0,10$ & $1,89 \pm 0,18$ & $<0,05$ \\
\hline & $5^{*}$ & $0,66 \pm 0,13$ & $1,27 \pm 0,22$ & $<0,05$ \\
\hline \multirow[t]{4}{*}{ Астенічні розлади } & 0 & $2,50 \pm 0,11$ & $2,46 \pm 0,12$ & $>0,05$ \\
\hline & 1 & $2,09 \pm 0,15$ & $2,10 \pm 0,13$ & $>0,05$ \\
\hline & 3 & $1,39 \pm 0,15$ & $1,55 \pm 0,14$ & $>0,05$ \\
\hline & $5^{*}$ & $0,85 \pm 0,14$ & $1,37 \pm 0,16$ & $<0,05$ \\
\hline Спрага & 0 & $1,86 \pm 0,15$ & $1,91 \pm 0,18$ & $>0,05$ \\
\hline
\end{tabular}


SSP Modern Pharmacy and Medicine (ISSN 2733-368X), Volume 1 Issue 1 August 2021

\begin{tabular}{|l|c|c|c|c|}
\hline & 1 & $1,08 \pm 0,17$ & $1,42 \pm 0,18$ & $>0,05$ \\
\cline { 2 - 5 } & $3^{*}$ & $0,88 \pm 0,15$ & $1,39 \pm 0,15$ & $<\mathbf{0 , 0 5}$ \\
\cline { 2 - 5 } & $5^{*}$ & $0,50 \pm 0,10$ & $0,98 \pm 0,14$ & $<\mathbf{0 , 0 5}$ \\
\hline \multirow{4}{*}{ Нудота } & 0 & $1,70 \pm 0,16$ & $1,64 \pm 0,20$ & $>0,05$ \\
\cline { 2 - 5 } & $1^{*}$ & $0,91 \pm 0,10$ & $1,60 \pm 0,07$ & $<\mathbf{0 , 0 5}$ \\
\cline { 2 - 5 } & $3^{*}$ & $0,46 \pm 0,08$ & $0,97 \pm 0,07$ & $<\mathbf{0 , 0 5}$ \\
\hline \multirow{4}{*}{ Діарея } & $5^{*}$ & $0,24 \pm 0,04$ & $0,87 \pm 0,12$ & $<\mathbf{0 , 0 5}$ \\
\cline { 2 - 5 } & 0 & $1,60 \pm 0,14$ & $1,54 \pm 0,20$ & $>0,05$ \\
\cline { 2 - 5 } & $1^{*}$ & $0,96 \pm 0,11$ & $1,65 \pm 0,08$ & $<\mathbf{0 , 0 5}$ \\
\cline { 2 - 5 } & $3^{*}$ & $0,46 \pm 0,08$ & $1,01 \pm 0,07$ & $<\mathbf{0 , 0 5}$ \\
\hline Парестезії & $5^{*}$ & $0,24 \pm 0,04$ & $0,82 \pm 0,14$ & $<\mathbf{0 , 0 5}$ \\
\cline { 2 - 5 } & 0 & $0,91 \pm 0,14$ & $0,81 \pm 0,16$ & $>0,05$ \\
\cline { 2 - 5 } & 1 & $0,49 \pm 0,12$ & $0,40 \pm 0.14$ & $>0,05$ \\
\cline { 2 - 5 } & 3 & $0,21 \pm 0,08$ & $0,15 \pm 0,08$ & $>0,05$ \\
\hline
\end{tabular}

* Примітка. Результати представлені за схемою: середнє значення \pm довірчий інтервал для

$\mathrm{p}<0,05$.

Результати дослідження показали, що лазерний комплекс за анксіолітичним, снодійним ефектами перевершує стандарт традиційної медикаментозної терапії. Це можна побачити на прикладі купірування проявів інсомнічних розладів, тривоги, страху, дисфоричних корелятів запійних форм алкоголізації.

Це дозволяло підтримувати терапевтичну дозу гідазепаму в основній групі на мінімальних значеннях, по 20-40 мг вранці і вдень, і 40 мг на ніч (в деяких спостереженнях було достатнім призначення гідазепаму по 20 мг 3 рази на день), в групі контролю доза гідазепаму була на рівні 40 мг 3 рази на день. Призначення цієї терапевтичної дози в основній групі на 2-3-й день терапії дозволяло хворому засинати через 30-45 хвилин після вечірніх призначень, в групі контролю - через 60-90 хвилин. До 4-й день терапії час до засинання скорочувався до 20-30 хвилин, в групі контролю тримався на колишніх часових регістрах. Сон в основній групі був глибоким, міцним, з одиничними пробудженнями. Ці дані відрізнялися від групи контролю. Тривалість повноцінного сну в перші 2-3 дні терапії оцінювалали за спостереженнями персоналу як 6-7 годин, 3 наростаючим збільшенням на 5-6-й день до 8-9 годин. Результатом застосування традиційної терапії була тривалість сну на рівні 6-7 годин, яка зберігалася такою протягом усього курсу лікування.

Відсутність явищ гіперседації (ранкова i денна сонливість, загальмованість, уповільнення психічного реагування, недостатність концентрації уваги) $€$ важливою позитивною відмінністю використання лазерного комплексу від застосування традиційної терапії. Так, у контрольній групі седативна дія була більш вираженою, що виявлялося в порушенні 
(уповільненні) реакції на зовнішні подразники, загальною загальмованістю, млявістю вранці і протягом дня, хворі багато часу проводили в ліжку, були адинамічними.

Динаміка соматоневрологічних розладів у двох групах була також різною, що вказувало на різні вектори впливу проведених лікувальних заходів. Купірування явищ гіпергідрозу, тремору, ознобу, астенічних розладів, парестезій в обох групах відбувалося синхронно, без статистично вірогідних відмінностей. Зниження рівня вираженості цих симптомів тривалої алкоголізації лише на 5-й день в основній групі приводило до вірогідного купірування астенічного симптомокомплексу, в порівнянні з групою контролю.

Хороший клінічний ефект від проведеного лазерного комплексу було виявлено в основній групі впродовж купірування симптомів тахікардії, анорексії, спраги, нудоти і діареї. Хворі до 3-го дня лікування відзначали істотне поліпшення апетиту, відсутність сухості в ротовій порожнині, зниження рівня почуття спраги, зменшувалася кількість випитої води. У пацієнтів вперше після пережитого абузусу відновлювалося бажання поїсти, випити гарячого чаю. В основній групі стабілізація даних параметрів була особливо помітною на тлі купірування нудотно-блювальних ранкових позивів і явищ тяжких тенезмів 3 діаретичними розладами, частим і рідким випорожненням.

Таким чином, дослідження показало, що найбільш значущими терапевтичними ефектами лазерної детоксикації $\epsilon$ анксіолітичний, антіастенічний, снодійний, антигастритичний, антиаритмічний.

Дослідження показало зовсім схожу за клінічною картиною тенденцію до нормалізації в основній і контрольній групах рівнів показників артеріального тиску (АТ) (стабілізація АТ в обох групах на рівні $\approx 140 / 90$ мм рт. ст.), частоти серцевих скорочень ( $\approx 70-74$ ударів на хвилину), дихальних рухів $(\approx 18-20$ за хвилину), електрокардіографічних даних (редукція розладів ритму і провідності серця), РЕГ (збільшення величини пульсового кровонаповнення, зменшення периферичного судинного опору, нормалізації венозного кровообігу) та ЕЕГ досліджень (значне зменшення вираженості патологічних форм активності, покращення вираження альфа-ритму і збільшення альфа-індексу).

Дисфункція печінки є одним із ключових симптомів запійної алкоголізації, що визначається при клінічному і лабораторних дослідженнях. Консультативний огляд терапевта в більшості наших спостережень діагностував в основній і контрольній групах алкогольний фіброз, гепатоз, гепатит, який був комбінацією стеатозу і дифузного запалення. У деяких випадках були присутні клінічні риси початкових форм цирозу печінки. Об'єктивно при аналізі соматичних скарг у хворих основної та контрольної груп переважала вісцеральна симптоматика в структурі абстиненції (біль у шлунку, нудота, блювання, метеоризм, рідке випорожнення, субіктеричність склер, стенокардія, аритмія серця, задишка). У всіх пацієнтів під час госпіталізації спостерігалася гіперферментемія, яка свідчить про токсичне ураження печінки. У багатьох хворих були ознаки постінтоксикаційної енцефалопатії, як правило, середньої тяжкості з класичними церебральними симптомами (головний біль, запаморочення). 
У процесі купірування запійних форм алкогольної залежності були вивчені біохімічні показники крові: активність печінкових ферментів (аспартатамінотрансферази, аланінамінотрансферази гаммаглутамілтрансферази), загальний білірубін, холестерин, лужна фосфатаза. Всі пацієнти були обстежені в період гострого запійного стану і після остаточного усунення цих явищ (1-й день госпіталізації і 7-й день лікування). Зміни величин біохімічних показників крові виражалися в наступному: активність АсАТ в сироватці крові на тлі комплексної детоксикації знижувалася на 40-45\%, АлАТ - на 45-60\%, також чітко спостерігалося зниження активності лужної фосфатази, рівнів показників вмісту холестерину, білірубіну. Рівень показників вмісту ГГТ залишався до 7-го дня спостереження підвищеним, але відзначалася виразна динаміка покращення значень показників, що чітко спостерігалося в основній і контрольній групі (Табл. 5).

Таблиця 5. Динаміка рівнів біохімічних показників у процесі лазерної детоксикації.

\begin{tabular}{|c|c|c|c|c|c|c|}
\hline $\begin{array}{c}\text { Група } \\
\text { обстеження }\end{array}$ & $\begin{array}{l}\text { АсAT, } \\
\text { МО/л }\end{array}$ & $\begin{array}{l}\text { АлАТ, } \\
\text { МО/л }\end{array}$ & $\begin{array}{c}\text { Холестерин, } \\
\text { ммоль/л }\end{array}$ & $\begin{array}{c}\text { Лужна } \\
\text { фосфатаза, } \\
\text { ОД }\end{array}$ & $\begin{array}{l}\text { Загальний } \\
\text { білірубін, } \\
\text { мкмоль/л }\end{array}$ & $\begin{array}{l}\text { ГГТ, } \\
\text { ОД/л }\end{array}$ \\
\hline \multicolumn{7}{|c|}{ 1-й день (госпіталізація) } \\
\hline Основна & $73,40 \pm 3,43$ & $82,20 \pm 3,63$ & $10,85 \pm 1,13$ & $225,0 \pm 21,0$ & $65,9 \pm 6,6$ & $98,60 \pm 4,56$ \\
\hline Контрольна & $69,40 \pm 4,09$ & $79,40 \pm 4,31$ & $11,78 \pm 1,50$ & $249,0 \pm 18,7$ & $60,9 \pm 9,6$ & $108,50 \pm 6,41$ \\
\hline \multicolumn{7}{|c|}{ 7-й день } \\
\hline Основна & $54,80 \pm 2,07^{*}$ & $65,40 \pm 3,35^{*}$ & $8,45 \pm 0,50$ & $142,0 \pm 13,7^{*}$ & $28,7 \pm 1,3^{*}$ & $64,00 \pm 5,43^{*}$ \\
\hline Контрольна & $61,70 \pm 3,25$ & $71,30 \pm 3,27$ & $8,89 \pm 0,70$ & $179,5 \pm 14,7$ & $32,3 \pm 1,3^{*}$ & $71,70 \pm 8,21^{*}$ \\
\hline
\end{tabular}

* Відмінності вірогідні порівняно 3 результатами дослідження в день госпіталізації $(\mathrm{p} \leq 0,05)$.

У процесі застосування лікувальної програми були проаналізовані значення коефіцієнта де Рітіса (співвідношення активності сироваткових АсТ і АлТ). Як відомо, значення коефіцієнта в нормі становить $1,33 \pm 0,42$ або 0,911,75 .

Відношення $<1,0$ вказує на легке ураження печінки i часто пов'язане із захворюваннями запального характеру. Відношення $\geq 1,0$ вказує на тяжке ураження печінки, що як правило, супроводжується некрозом.

У наших спостереженнях показник співвідношення менше «1» свідчить про алкогольне ураження печінки. Високі рівні ферментемії упродовж запійних станів характеризуються низьким коефіцієнтом де Рітіса і прогностично $\epsilon$ несприятливою ознакою перебігу хвороби (Табл. 6). 
SSP Modern Pharmacy and Medicine (ISSN 2733-368X), Volume 1 Issue 1 August 2021

Таблиця 6. Динаміка коефіцієнта де Рітіса в процесі тандемної лазерної детоксикації.

\begin{tabular}{|c|c|c|c|}
\hline \multirow[t]{2}{*}{ Група обстеження } & \multicolumn{3}{|c|}{ Коефіцієнт де Рітіса } \\
\hline & 1-й день & 7-й день & $\begin{array}{c}\text { Значення р у } \\
\text { внутрішньогрупових } \\
\text { порівняннях } \\
\end{array}$ \\
\hline Основна & 0,89 & 0,83 & $\mathrm{p}>0,05$ \\
\hline Контрольна & 0,87 & 0,86 & $\mathrm{p}>0,05$ \\
\hline 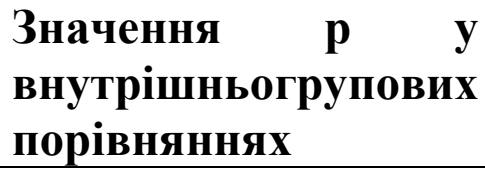 & $\mathrm{p}>0,05$ & $\mathrm{p}>0,05$ & \\
\hline
\end{tabular}

В основній групі спостерігалася незначне збільшення рівня коефіцієнта де Рітіса до 7-го дня терапії, яке було статистично вірогідно. У групі контролю значення було практично без змін.

Використання шкали «Загальне клінічне враження» дозволило підтвердити хороший терапевтичний ефект комплексу. За субшкалою «Тяжкість стану» скринінг проводили відповідно до рубрифікації: 1 - здоровий, жодних розладів; 2 - граничні психічні розлади; 3 - легкі розлади; 4 - помірні розлади; 5 - виражені розлади; 6 - тяжкі розлади; 7 - розлади 3 категорії найтяжчих. В основній групі середній бал суб'єктивного сприйняття тяжкості стану хворого склав 2,44 $\pm 0,34$, в контрольній $3,15 \pm 0,12$ ( $>0,05$ ), статистично вірогідної різниці у групах не виявлено.

За субшкалою «Загальне враження» оцінювали загальний стан в порівнянні зі станом хворого в день госпіталізації: 0 - оцінювання не проводили; 1 - дуже значне поліпшення; 2 - значне поліпшення; 3 - мінімальне поліпшення; 4 - без змін; 5 - мінімальне погіршення; 6 - значне погіршення; 7 - дуже значне погіршення. В основній групі середній бал загального стану хворого склав 2,24 $\pm 0,55$, в контрольній $3,45 \pm 0,12$ ( $<<0,05)$, виявлена статистично вірогідна різниця в групах.

Безпечність та переносність лазерного терапевтичного комплексу оцінювали за допомогою контролю небажаних явищ, про які спорадично повідомляли пацієнти або які помічали лікар та персонал. Терапія із застосуванням інноваційного лазерного алгоритму відрізнялася високою безпекою, хворі іiі добре перенесли. У пацієнтів не виникало небажаних явищ, ускладнень, побічних ефектів, обтяження стану. Аналізуючи позитивний досвід застосування нового в наркології лікувального модуля, слід зазначити відсутність жодних небажаних побічних ефектів, специфічних смакових або тілесних відчуттів на тлі проведеної терапії.

Висновки. На підставі вище представлених даних можна зробити висновок про високу ефективність лазерної інфузійної детоксикації як засобу купірування запійної форми алкогольної залежності. Темпи редукування соматоневрологічних і психопатологічних розладів були істотно вищими у разі застосування інноваційного лікувального модуля на основі лазерних технологій, 
ніж у процесі терапії традиційними медикаментозними засобами. Клінічне трактування отриманих результатів в основній групі дозволило зафіксувати тенденцію до більш виразної позитивної динаміки, яка виявлялася в більш плавному зникненні постінтоксикаційної симптоматики. Цю ж динаміку продемонстрував і моніторинг рівнів біохімічних показників, що свідчить про гепатотропні ефекти запропонованого методу терапії. На нашу думку, основною клінічною особливістю застосування лазерного комплексу $\epsilon$ відмінності в інтенсивності настання позитивного лікувального ефекту, що свідчать про наявність виражених детоксикаційних властивостей.

Таким чином, лікувальні ефекти запропонованої лазерної детоксикаційної програми $\epsilon$ надзвичайно потрібними для купірування запійної форми алкогольної залежності в наркологічній практиці. Отримані результати розширюють сучасні можливості етіопатогенетичної терапії і дозволяють рекомендувати включення розробленого методу в комплексні терапевтичні і відновно-реабілітаційні програми лікування наркологічних хворих.

\section{Список літератури.}

1. Narkolohiia: Natsionalnyi pidruchnyk z hryfom MON ta MOZ [Tekst] / Sosin I.K., Chuiev Yu.F., Artemchuk A.P. [ta in.]; za red. I.K. Sosina, Yu.F. Chuieva. — Kh.: Vyd-vo «Kolehium», 2014. - $1500 \mathrm{~s}$.

2. Psykhiatriia i narkolohiia: pidruchnyk /O. K. Naprieienko, M.I. Vynnyk, I.I. Vlokh [ta in.]; za red. O.K. Naprieienka. - K.: Medytsyna, 2011. - 527 s.

3. Sosin I. K., Honcharova O. Yu., Mysko H. M., Lisova Ye.V., Babenko Ye.Iu., Chuiev Yu. F. Klinichna narkolohiia: pidruchnyk bezperervnoho profesiinoho rozvytku / Za redaktsiieiu prof. V.H. Marchenko. KhMAPO, Kharkiv : Kolehium, 2020. $-1080 \mathrm{~s}$.

4. Chaban O.S. Nevidkladna dopomoha v psykhiatrii ta narkolohii / O.S. Chaban, O.O. Khaustova, Ya.M. Nestorovych. - K.: Medknyha, 2010. - 131 s.: tabl., il.

5. Sosin I.K., Chuev Yu.F. Lazernaya terapiya $\mathrm{v}$ narkologii. $\mathrm{V}$ kn.: Sovremennyie aspektyi lazernoy terapii. \Pod red. V.D. Popova. Cherkassyi: Vertikal, izdatel Kandyich S.G. - 2011. - S. 472-526.

6. Sosin I.K., Chuiev Yu.F., Honcharova O.Iu., Horban A.Ie., Petriuk P.T., Shevchenko N.O., Zakrevskyi O.P., Kiosiev O.V., Skobeliev V.O. Poiednannia likuvalnykh efektiv suchasnykh nemedykamentoznykh ta farmakolohichnykh metodiv terapii pry alkohol-asotsiiovanykh zakhvoriuvanniakh pechinky. Materyalы KhLIII Mezhdunarodnoi nauchno-praktycheskoi konferentsyy «Prymenenye lazerov v medytsyne y byolohyy», 27-30 maia 2015 hoda. - Kharkov, 2015. - S. 55-57. 